\title{
Impact of cockroach allergens on the immune response as an asthma trigger
}

\author{
Maryangela Godinho Pereira Bena' ${ }^{1}$, Iêda Maria Silva Araújo ${ }^{2}$, Bruna Katarine Beserra Paz ${ }^{3}$, \\ Giselmo Lopes Pinheiro ${ }^{4}$ and Angela Falcai ${ }^{5}$ \\ ${ }^{1}$ Universidade CEUMA - UniCEUMA, São Luís-Maranhão, Brasil \\ maryangelapereira@hotmail.com.br \\ ${ }^{2}$ Universidade CEUMA - UniCEUMA, São Luís-Maranhão, Brasil \\ iedamed@gmail.com \\ ${ }^{3}$ Universidade CEUMA - UniCEUMA, São Luís-Maranhão, Brasil. \\ bkpaz@hotmail.com \\ ${ }^{4}$ Universidade CEUMA - UniCEUMA, São Luís-Maranhão, Brasil \\ giselmopinheiro@hotmail.com \\ ${ }^{5}$ Universidade CEUMA - UniCEUMA, São Luís-Maranhão, Brasil \\ angela.falcai@ceuma.br
}

\begin{abstract}
This work is a literature review that aims to provide a comprehensive overview of asthma and show the importance of cockroach allergens as a trigger for the disease, as well as highlight the immune mechanisms involved. Asthma is a public health problem, with a high global prevalence, especially in children and adolescents, characterized by type 1 hypersensitivity. It is a multifactorial disease triggered by environmental, genetic, and immunological factors. Several articles have correlated asthma with cockroach allergens, and their prevalence has been increasing. Environmental conditions, low income, urban centers, and lack of basic sanitation are associated with cockroach infestations that contribute to asthma attacks. Identifying cockroach proteins capable of triggering asthma, and elucidating the immunological mechanisms involved in responding to cockroach allergens is essential. This review concludes that the prevalence of asthma triggered by cockroach allergens is high. Only two allergenic cockroaches, Blatella germanica and Periplaneta americana, have been identified with 11 and 12 allergens, respectively. Furthermore, there are very few studies that detail how the immune system of asthmatic children behaves in the face of these cockroach allergens.
\end{abstract}

Keywords: Immunology; Allergens; Cockroach; Environmental 


\section{Introdution}

Asthma is a multifactorial disease, which results from a complex interaction between environmental, genetic, and immunological factors (HOLGATE, 2011). Most studies show that allergens present in the environment in combination with a genetic predisposition in individuals may lead to bronchial hyperreactivity, triggered by a type 1 or immediate immune response (BAO, 2017; TOSKALA, 2015). Among all categories, inhalant allergens were the principal cause of respiratory allergies, more specifically allergens from house dust mites (Dermatophagoides pteronyssinus (Der p), Dermatophagoides farinae (Der f), and Blomia tropicalis), cockroaches (Periplaneta americana (Per a), Blattella germanica (Bla g)), domestic animals (dogs and cats), and fungi (GIBSON, 2017; LAWSON, 2017). Exposure to environmental allergens early in life is one of the important determining factors for triggering allergic asthma (LYNCH, 2014).

Severe asthma mainly affects children and adolescents and has become a public health problem in the last few decades due to the increase in its prevalence worldwide. The main issues associated with this disease are high costs to the health system, sickness, and absence from work and school (CHUNG, 2018). The prevalence of asthma morbidity acquired through cockroach allergens may vary among the world's population. Estimations state that the incidence of cockroach induced allergies ranges from $17-41 \%$ in the US population, including both children and adults, and mainly affects urban and low-income families. It was also observed that $85 \%$ of the homes in city centers contain cockroach allergens and $60-80 \%$ of the children with asthma who live in these centers are sensitized to these allergens $(\mathrm{COHN}$, 2006; SVENDSEN, 2018).

House cockroaches include more than 25 species, but the predominant ones are as follows: the German cockroach (Bla g), commonly found in cold and dry climates, and the American cockroach (Per a), predominant in hot and humid areas (POMES, 2017). Efficient environmental control is essential to ensure a better quality of life and a decrease in the allergic crises. Literature indicates that awareness about the need to exterminate these pests and extermination of cockroaches in homes lowers the numbers of these insects and in turn, decreases the asthma crisis. Effective control of pests can be done with inexpensive insecticide baits (CHEN, 2015; TSCHUDY, 2017).

However, apart from environmental control, it is essential to know the physiology of these allergies, that is, identification of the most allergenic proteins and the immunological mechanisms involved in the recognition of these allergens and the cellular activation pathways. These are vital for elucidating the pathological mechanisms of the disease, and consequently, may help in the search for new therapies. This article aims to provide a comprehensive overview of asthma by detailing the importance of cockroach allergens as triggers for this disease and highlight the immune mechanisms involved in the recognition and activation of cells and molecules specific to asthma patients.

\section{Review}

\subsection{Asthma}

Asthma is considered a chronic disease characterized by airway hyperresponsiveness that manifests with recurrent episodes of wheezing, shortness of breath, tightness in the chest, and coughing, particularly at night or early in the morning (COLLABORATORS, 2017). The classification according to severity is mild, moderate, and severe, with severe asthma occurring early in life and usually being associated with atopic conditions and corresponding to $50 \%$ of healthcare costs (GUILBERT, 2014).

According to ISAAC (International Study of Asthma and Allergies in Childhood), asthma can affect up to 334 
million people (INTERNATIONAL SOCIETY FOR, 2014). In Latin America, the prevalence of childhood asthma ranges from $4-30 \%$, with a high rate of severe asthma. According to data made available in 2015 by the Brazilian government, asthma is responsible for 100,000 hospitalizations in the single health system (SUS), and according to the Hospital Information System (SIH), these hospitalizations cost about R \$ 57.2 million in the public health network. Despite the efforts to implement asthma centers and programs in order to reduce the rates of asthma hospitalizations in Brazil, there is still a lack of planning in several phases (conception, implementation, and maintenance). There are also high rates of physical inactivity, absenteeism of children from school, and hence parents from work. The Global Asthma Network (RIBEYRE) was therefore created with the aim of reducing the number of severe asthma cases by $50 \%$ worldwide by 2025 .

The pathophysiology of asthma is characterized by a type 1 or immediate hypersensitivity response. This response initiates with the sensitization of the individual to the allergen. Dendritic cells recognize an allergen and present them to naive $\mathrm{T}$ lymphocytes, which differentiate into type 2 lymphocytes (Th2 lymphocytes), mainly producing interleukin 4 (IL-4), IL-5, and IL-13 (LIANG, 2017). More recently, a new cell type was discovered, the innate lymphoid cells of group 2 (ILC2), which belong to the innate immune system and are producers of IL-4, IL-5, and IL-13 that function collaboratively to produce a Th2-type immune response (WANG, 2017).

The cytokines IL-4, IL-5, and IL-13 activate eosinophils and B-lymphocytes, which differentiate into plasmocytes that are producers of immunoglobulin E (IgE). Mast cells present on the tissues have on their surface a high-affinity IgE receptor, called CD23. The circulating IgE binds to CD23, and after repeated exposure to allergens, the mast cell is activated and degranulates mediators, such as biogenic amines (for example, histamine, prostaglandin, leukotrienes, and thromboxanes), cytokines (tumor necrosis factor (TNF)- $\alpha$ ) and enzymes related to vasodilation, vascular extravasation, bronchoconstriction, intestinal hypermotility, inflammation, and tissue injury (BARBER, 2017; WU, 2014) (Figure 1). Besides, other cytokines described as essential for the inflammatory process of asthma, such as IL-17 produced by Th17 lymphocytes, have neutrophil recruitment capabilities and are related to the increase of serum cytokine levels in patients with neutrophilic asthma (WANG, 2018).

Immunological studies have been published and discuss the possible mechanisms involved in the pathophysiology of asthma, a topic that is still under debate. For a long time, the theory of hygiene was the favored hypothesis, which consisted of sensitizing patients to allergens in the first months of life. Studies suggested that high exposure to endotoxin in early life leads to development of a Th1 response, whereas low exposure to endotoxin leads to a Th2 type immune response, favoring allergies (VILLENEUVE, 2017). However, other studies have shown that nonwheezing children who were exposed to high endotoxin levels and whose peripheral blood mononuclear cells (PBMCs) were stimulated with lipopolysaccharide (LPS) early in life (two years of age), produced high levels of IL-12 and IFN$\gamma$, a Th1-type response. However, even when exposed to high levels of endotoxin, PBMCs in wheezing children were not able to produce Th1-type cytokines, suggesting a Th1-axis deficiency (FALCAI, 2012).

Furthermore, studies of genetic polymorphisms have also been published in order to elucidate the genetic defects leading to asthma, such as single nucleotide polymorphisms (SNP) in the filaggrin gene (RS 11204981) (PAVLYK, 2016), haplotypes in the leukocyte antigen numbers of polymorphisms of pentanucleotides (HIRAI, 2018), CD14 (NIETO-FONTARIGO, 2018), TAP-1 (HLA-g) (RIBEYRE, 2018), ADRB2 (SENN, 2018), NOS2 (HANG, 2003), cytokines TNF- $\alpha$ (MAKAMURE, 2016), IL-1 $\beta$ (BIRBIAN, 2013), IL-13 (XU, 2017), and TLR4 (YAO, 2014).

The immunological mechanisms studied were fundamental to the development of strategies for the treatment of asthmatic patients. Currently, there are therapies such as the use of corticosteroids, $\beta 2$-AR agonists, and leukotriene 
modulators (DURHAM, 2017), and immunotherapies to desensitize patients to allergens, and in more severe cases, blockage of the main proinflammatory cytokines such as IL- 5, IL-13, IL-4, or IL-17 is carried out (PELAIA, 2017; WALSH, 2017). Recent studies show a possible future for pharmacogenetic and pharmacogenomic interventions (LIANG, 2017; VIJVERBERG, 2018).

However, adherence to asthma treatment is a problem all over the world. There are difficulties even in developed countries: health professionals are not familiar with the newly available therapies and socioeconomic limitations, one of the main problems patients suffer from (BARRETO et al., 2014). It is possible to identify the allergens to which the individual is sensitized to - through measuring IgE by RAST and/or testing hypersensitivity by prick test, and take preventive measures to reduce asthma attacks via environmental intervention.. Among the main environmental factors associated we focus on cockroaches in this review.

Figure 1. Immunological mechanisms of asthma. TH2 (Type 2 lymphocytes). ILC-2 (lymphoid cells 2). M (mast cells). E (eosinophils). IgE (Immunoglobulin E), IL (Interleukins). B (B lymphocytes). CD23 (High-affinity IgE receptor).

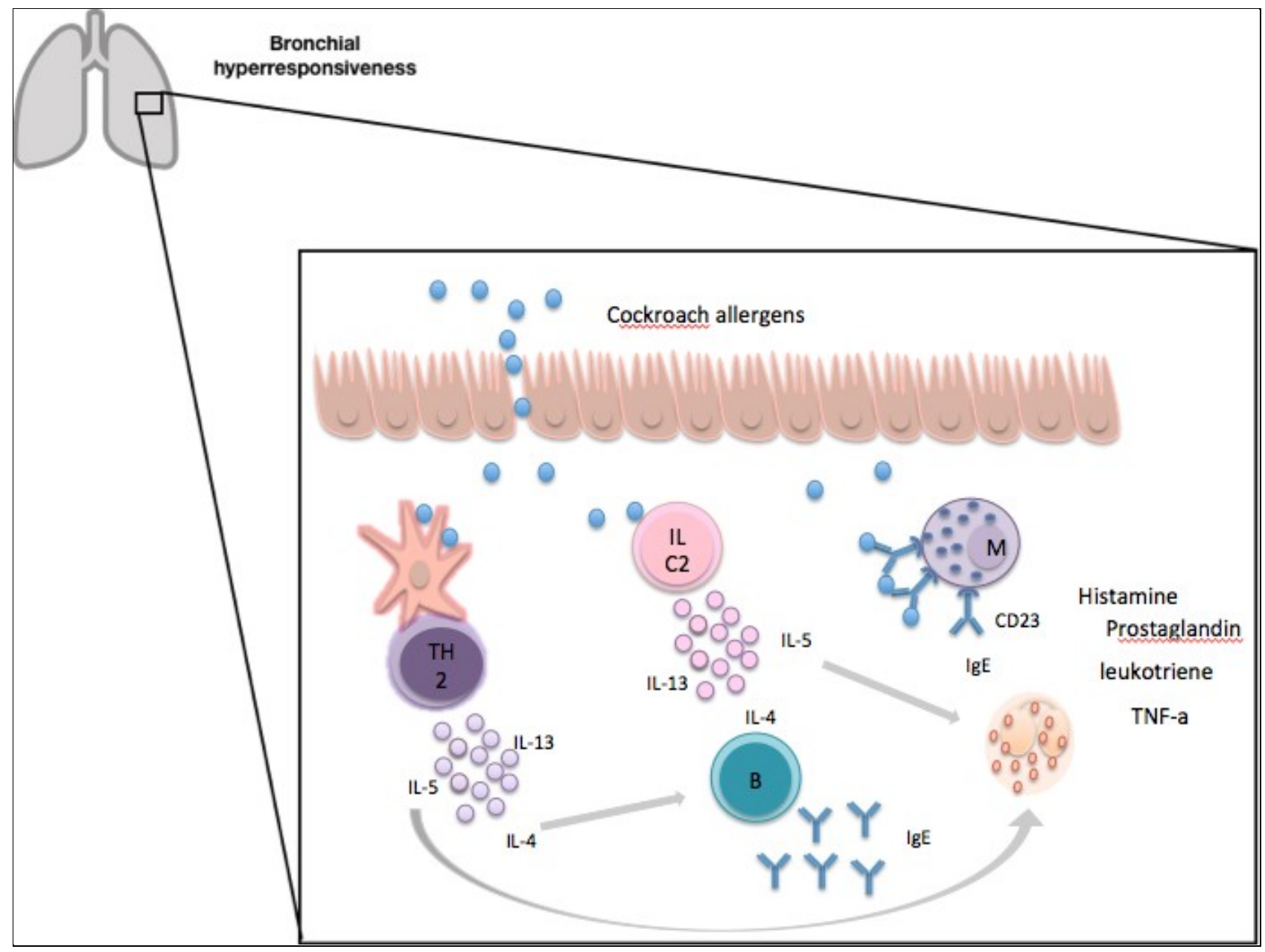

\subsection{Asthma and Cockroaches}

Cockroaches are considered pests and they are distributed worldwide. Cockroach infestations occur in various types of human dwellings, including hospitals, homes, and schools. Environmental factors, such as sites that are not 
suitable for housing, low economic status, and lack of basic sanitation, contribute to their dissemination (MEMONA, MANZOOR and RIAZ, 2017). Cockroach infestations are a serious public health problem because in addition to causing contamination of food by pathogenic microorganisms such as bacteria, fungi, and viruses, they are themselves a source of allergens that trigger allergic diseases, mainly asthma (ARRUDA, 2001).

In 1964, in New York, Bernton and Brown used a cockroach extract to perform the hypersensitivity skin test, reporting positive allergenic reactions (BERNTON, 1964). In 1979, a group of researchers demonstrated early and late bronchoconstriction after the inhalation of cockroach extract by asthmatic patients, thus establishing a relationship between the cockroach proteins and asthma (KANG, 1979). From there, successive studies have shown that exposure to cockroach allergens increases morbidity and asthma attacks in children and adults (AHMADIAFSHAR, 2016; EGGLESTON, 2017; LAN, 1988; O'CONNOR, 1999; SAKAGUCHI, 1994; STELMACH, 2002).

An epidemiological study conducted in the United States confirmed that around $60-80 \%$ of children living in homes located in urban centers were sensitized to cockroaches, presenting a positive hypersensitivity test against them (SOHN, KIM, 2012). Other countries such as Poland reported that approximately $25 \%$ of asthmatic children are sensitized to cockroaches, and most households have detectable levels of allergens in household dust (STELMACH et al., 2002). In Asia, cockroach allergens are found in 11-98\% of household dust samples (ZHENGEN et al., 2015). In Taiwan, 58\% of asthmatics are sensitized to the Per 2 allergen, which corroborates that exposure and sensitization to cockroach allergens are relevant in the development of allergic asthma across the continent (LEE et al., 2012).

Environmental interventions have also been described and show signs of success. A study identified asthmatic children sensitized to cockroaches and carried out an intervention in their houses using cockroach pesticides. At the end of their study, it was concluded that this intervention diminished the asthma crisis (GERGEN, 1999). However, this approach does not work in all cases; for example, German cockroaches present in residences are resistant to multiple insecticides. This resistance coupled with the high reproductive potential of the cockroach means that the practice of environmental pest control becomes ineffective (WEI, 2001). Another vital point to be discussed is the exposure to insecticide and herbicide residues indoors, which has a potential health risk, especially for children and pregnant women (WHYATT, 2002).

The detection of these asthma trigger factors is fundamental for a good quality of life of asthmatic individuals, since the reduction of the exposure depends on the identification and removal of facilitating factors, such as food debris, lack of basic sanitation, and cleaning, which are an entry point for increased morbidity.

\subsection{Cockroach Allergens}

The allergy is caused by the particles present in the saliva, fecal material, spermatophore, and desiccated remains of the cockroach (FUJIKAWA, 2015; KNIGHT et al., 2001). Cockroach allergens constitute a vast group of proteins that have been identified, sequenced, purified, and produced as biologically active recombinant proteins in recent years. These cockroach allergens were only identified by molecular cloning conducted by the Allergen Nomenclature database of the World Health Organization and International Union of Societies of Immunology (WHO / IUIS) (FANG et al., 2015).

There are approximately 4,600 cockroach species distributed worldwide that are well adapted to a wide range of habitats. Most of them live in tropical forests and despite the diversity of species, only a few have adapted to human 
environments (MEMONA, 2017). Despite the existence of thousands of species of cockroaches, to date, only 50 have been reported as plagues that have adapted to the domestic habitat. Those that predominate are as follows: the German cockroach and the American cockroach. Their allergens vary between populations depending on location and climatic factors (SOOKRUNG, 2010).

The German cockroach is most commonly found in cold and dry climates. Its preferred habitat is in kitchens and storage areas, especially where food is being prepared or stored (UIEDA, 2014). The American cockroach is predominant in hot and humid regions and is found in sewers and basements, especially around pipes and drains (CHEN, 2016). In Brazil, the predominant cockroach species is Periplaneta americana, and IgE reactivity to the Per 1 allergen varies in Brazil, while in Taiwan and Thailand, the reactivity reaches $50 \%$ and $100 \%$, respectively (BARBOSA, 2013).

Currently, Bla $g$ has 11 allergens (Bla g 1-9 and Bla g 11), the first cockroach allergen to be cloned was Bla $g$ in 1995 (ARRUDAVAILESMANN, 1995), Bla $g 2$ is an aspartic protease, Bla $g$ is hemocyanin, Bla $g$ is a lipocalin, Bla $g 5$ is a glutathione S-transferase, Bla $g 6$ is a troponin C, Bla $g 7$ is a tropomyosin, Bla $g$ is a myosin light-chain, Bla $g$ is an arginine kinase, and Bla $g 11$ is an alpha-amylase (ARRUDAVAILESHAYDEN, 1995).

On the other hand, Per a contains 12 allergens (Per a 1-3; Per a 5-7 and Per a 9-12), where Per a 2 is a type of aspartic protease, Per $a 3$ is an arylphorin, Per $a 5$ is a glutathione $\mathrm{S}$-transferase, Per $a 6$ is a troponin $\mathrm{C}$, Per $a 7$ is a tropomyosin, Per $a 9$ is an arginine kinase, Per $a 10$ is a serine protease, Per $a 11$ is an alpha-amylase, and Per $a 12$ is a chitinase (ARRUDA, 2001).

Most of these allergens were detected as immunoglobulin E (IgE) ligands and possible allergy-triggering molecules in asthma. Based on the knowledge about the structure and function of cockroach allergens, we can develop better diagnosis and treatment strategies for allergen exposure.

\subsection{Innate and adaptive immune response to cockroach allergens}

The innate immune response is triggered by the inhalation of the cockroach allergens. Bla $g 1$ activates natural killer cells by increasing the expression of IL-9, IL-13, and CCL17 (ALTMAN, 2018). Experiments with Bla $g$ 2 revealed the importance of basophils in the production of IL-4 and histamine, in addition to suggesting the involvement of DC-SIGN and DCRR (DO, 2017). The Bla $g 3$ allergen is a molecule capable of activating human beta-defensins in the mucous membranes (DIETRICH, 2014) (Figure 2).

The Per a 7 allergen can increase the expression of Toll-like receptors (TLR), mainly TLR9 (YANG, 2012), and Per a 10 polarizes dendritic cells (DC) to a type 2 phenotype, with increased production of IL-4, IL-5, IL-6 and TNF-alpha and low IL-10 release. Moreover, Per a 10 modulates the expression of CD40 in dendritic cells via NF- $\kappa \mathrm{B}$ (nuclear kappa B Factor) signaling pathway, and suppresses IL-12 production by DCs, which favours a Th2 response (GOEL, 2015) (Figure 2).

Studies also show single nucleotide polymorphisms (SNPs) in innate immunity molecules, such as mannosebinding lectin (MBL), IL-12A, TLR6, HLA, IL5RA, ADAM33, and CD14, associated with cockroach allergens (GAO, 2014, SOKOLOWSKA, 2017).

Regarding adaptive immunity, the experiments with the Per a 10 allergen showed that the molecule could activate calcium and MAPK signaling pathways via PAR2 (POLLEY, 2017), and polarize Th2 lymphocytes with high production of IL-23 and OX40L (AGRAWAL, 2015). Additionally, studies in mice suggest that the cockroach extract activates a Th2 immune response, producing cytokines IL-4, IL-5, IL-13, and IFN- $\gamma$ (LIM, 2017). Asthmatic children 
sensitized to cockroach allergens have also been reported to produce high levels of IL-4, IL-10, IL-17F, IL-21, IL-25, IL-31, IFN- $\gamma$, and TNF-alpha, and low IL17A levels (MEDSKER, 2017).

Figure 2. Innate immune responses to cockroach allergens. Bla $g 1$ (allergen 1 from cockroach Blatella germanica). Bla g 2 (allergen 2 from cockroach Blatella germanica). Bla g 3 (allergen 3 from cockroach Blatella germanica). Per a 7 (allergen 7 from Periplaneta americana cockroach). Per a 10 (allergen 10 from Periplaneta americana cockroach). IL (Interleukins). TLR9 (receptor of type Toll 9). CCL17 (chemokine). TNF- $\alpha$ (tumor necrosis factor alpha). NFאB (K beta transcription factor).

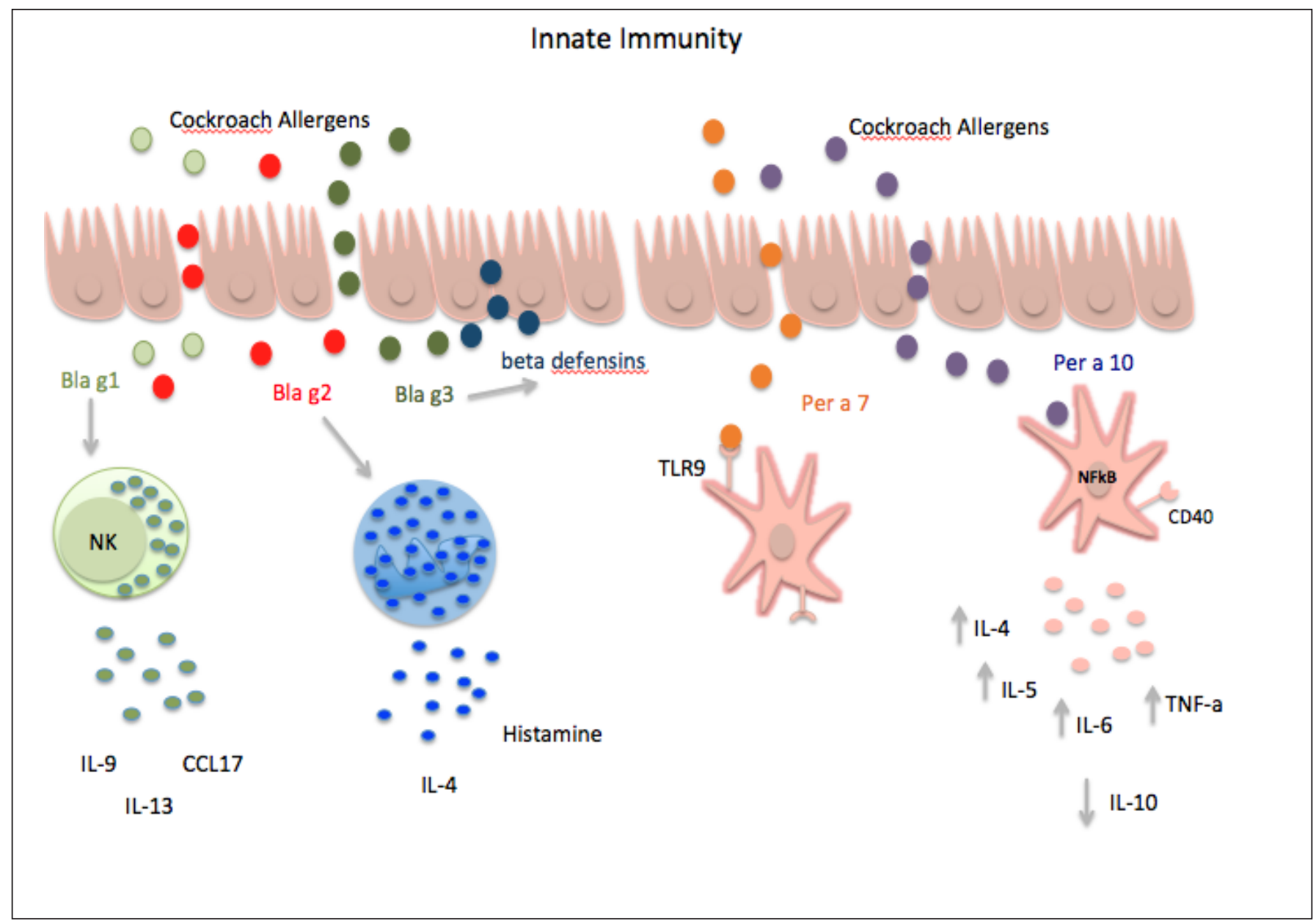

\section{Conclusions}

We conclude that asthma is a public health problem, with a high prevalence worldwide, especially in children and adolescents. There are recent publications of cells, such as ILC2, found to be involved in the immunological mechanisms of asthma. Cockroaches are risk factors for sensitization and triggering of asthma attacks, especially in urban populations, and these effects might be related to non-ideal living conditions, such as lack of basic sanitation and low family income. The most allergenic cockroaches are the Bla $g$ and Per $a$. To date, 11 allergens have been described for Bla $g$ and 12 for Per $a$. 
However, there have been few scientific studies on the innate or adaptive immunological mechanisms induced by cockroach antigens. Identification of allergens and an understanding of the mechanisms involved in cockroachinduced asthma are essential for the rapid and adequate diagnosis and developing new therapies.

\section{Acknowledgments}

We thank Dra. Rita de Cássia Mendonça de Miranda for the helpful suggestions, the other collaborators, the funding agency FAPEMA, CNPq, and finally the University of CEUMA.

\section{References}

AGRAWAL, K.,KALE, S. L.,ARORA, N. Protease activity of Per a 10 potentiates Th2 polarization by increasing IL23 and OX40L. Eur J Immunol. Dec.2015;v.45:n.12:p.3375-85.

ALTMAN, M. C.,WHALEN, E.,TOGIAS, A.,O'CONNOR, G. T.,BACHARIER, L. B.,BLOOMBERG, G. R. et al. Allergen-induced activation of natural killer cells represents an early-life immune response in the development of allergic asthma. J Allergy Clin Immunol. Mar 5.2018.

ARRUDA, L. K.,FERRIANI, V. P.,VAILES, L. D.,POMES, A.,CHAPMAN, M. D. Cockroach allergens: environmental distribution and relationship to disease. Curr Allergy Asthma Rep. Sep.2001;v.1:n.5:p.466-73.

BIRBIAN, N.,SINGH, J.JINDAL, S. K. High risk association of IL-1 receptor antagonist (IL-1RN) VNTR polymorphism with asthma in a North Indian population: a pilot study. Cytokine. Jun.2013;v.62:n.3:p.389-94.

CHEN, Y.,HE, M.,LI, Z. Q.,ZHANG, Y. N.,HE, P. Identification and tissue expression profile of genes from three chemoreceptor families in an urban pest, Periplaneta americana. Sci Rep. Jun 9.2016;v.6:p.27495.

CHUNG, K. F. Diagnosis and Management of Severe Asthma. Semin Respir Crit Care Med. Feb.2018;v.39:n.1:p.9199.

COHN, R. D.,ARBES, S. J., JR.,JARAMILLO, R.,REID, L. H.,ZELDIN, D. C. National prevalence and exposure risk for cockroach allergen in U.S. households. Environ Health Perspect. Apr.2006;v.114:n.4:p.522-6.

DIETRICH, D. E.,MARTIN, A. D.,BROGDEN, K. A. Human beta-defensin HBD3 binds to immobilized Bla g2 from the German cockroach (Blattella germanica). Peptides. Mar.2014;v.53:p.265-9.

FALCAI, A.,PEREIRA, P. V.,KUBO, C. A.,RULLO, V.,ERRANTE, P. R.,SOLE, D. et al. Leukocytes from wheezing infants release lower amounts of IL-12 and IFN-gamma compared to non-wheezing infants. Pediatr Pulmonol. Nov.2012;v.47:n.11:p.1054-60.

GERGEN, P. J.,MORTIMER, K. M.,EGGLESTON, P. A.,ROSENSTREICH, D.,MiTCHELL, H.,OWNBY, D. et al. Results of the National Cooperative Inner-City Asthma Study (NCICAS) environmental intervention to reduce cockroach allergen exposure in inner-city homes. J Allergy Clin Immunol. Mar.1999;v.103:n.3 Pt 1:p.501-6.

GOEL, C.,KALRA, N.,DWARAKANATH, B. S.,GAUR, S. N.,ARORA, N. Per a 10 protease activity modulates CD40 expression on dendritic cell surface by nuclear factor-kappaB pathway. Clin Exp Immunol. May.2015;v.180:n.2:p.34151.

GUILBERT, T. W.,BACHARIER, L. B.,FITZPATRICK, A. M. Severe asthma in children. J Allergy Clin Immunol Pract. Sep-Oct.2014;v.2:n.5:p.489-500.

HIRAI, K.,SHIRAI, T.,SUZUKI, M.,SHIMOMURA, T.,ITOH, K. Association between (CCTTT)n repeat polymorphism in NOS2 promoter and asthma exacerbations. J Allergy Clin Immunol. Mar 5.2018.

HOLGATE, S. T. Asthma: a simple concept but in reality a complex disease. Eur J Clin Invest. Dec.2011;v.41:n.12:p.1339-52. 
INTERNATIONAL SOCIETY FOR, A.,ALTERNATIVE, C. ISAAC position statement on facilitated communication. International Society for Augmentative and Alternative Communication. Augment Altern Commun. Dec.2014;v.30:n.4:p.357-8.

KANG, B.,VELLODY, D.,HOMBURGER, H.,YUNGINGER, J. W. Cockroach cause of allergic asthma. Its specificity and immunologic profile. J Allergy Clin Immunol. Feb.1979;v.63:n.2:p.80-6.

LIANG, P.,PENG, S.,ZHANG, M.,MA, Y.,ZHEN, X.,LI, H. Huai Qi Huang corrects the balance of Th1 /Th2 and Treg /Th17 in an ovalbumin -induced asthma mouse model. Biosci Rep. Nov 21.2017.

LYNCH, S. V.,WOOD, R. A.,BOUSHEY, H.,BACHARIER, L. B.,BLOOMBERG, G. R.,KATTAN, M. et al. Effects of early-life exposure to allergens and bacteria on recurrent wheeze and atopy in urban children. J Allergy Clin Immunol. Sep.2014;v.134:n.3:p.593-601 e12.

MAKAMURE, M. T.,REDDY, P.,CHUTURGOON, A.,NAIDOO, R. N.,MENTZ, G.,BATTERMAN, S. et al. Tumour necrosis factor alpha polymorphism (TNF-308alpha G/A) in association with asthma related phenotypes and air pollutants among children in KwaZulu-Natal. Asian Pac J Allergy Immunol. Sep.2016;v.34:n.3:p.217-222.

MEDSKER, B. H.,FORNO, E.,HAN, Y. Y.,ACOSTA-PEREZ, E.,COLON-SEMIDEY, A.,ALVAREZ, M. et al. Cockroach allergen exposure and plasma cytokines among children in a tropical environment. Ann Allergy Asthma Immunol. Jul.2017;v.119:n.1:p.65-70 e3.

MEMONA, H.,MANZOOR, F.,RIAZ, S. Species Diversity and Distributional Pattern of Cockroaches in Lahore, Pakistan. J Arthropod Borne Dis. Jun.2017;v.11:n.2:p.249-259.

NIETO-FONTARIGO, J. J.,SALGADO, F. J.,SAN-JOSE, M. E.,CRUZ, M. J.,CASAS-FERNANDEZ, A.,GOMEZCONDE, M. J. et al. The CD14 (-159 C/T) SNP is associated with SCD14 levels and allergic asthma, but not with CD14 expression on monocytes. Sci Rep. Mar 7.2018;v.8:n.1:p.4147.

PAVLYK, O.,IEMETS, O.,STROY, D.,VOLOSOVETS, O.,KRYVOPUSTOV, S.,DOSENKO, V. Single-nucleotide polymorphism (rs11204981) in filaggrin gene and its functional significance for asthma among children with eczema. Fiziol Zh.2016;v.62:n.3:p.3-8.

POMES, A.,MUELLER, G. A.,RANDALL, T. A.,CHAPMAN, M. D.,ARRUDA, L. K. New Insights into Cockroach Allergens. Curr Allergy Asthma Rep. Apr.2017;v.17:n.4:p.25.

RIBEYRE, C.,CARLINI, F.,RENE, C.,JORDIER, F.,PICARD, C.,CHIARONI, J. et al. HLA-G Haplotypes Are Differentially Associated with Asthmatic Features. Front Immunol.2018;v.9:p.278.

SENN, S. Childhood asthma exacerbations and ADRB2 polymorphism: Caution is needed. J Allergy Clin Immunol. Mar 6.2018.

SOOKRUNG, N.,CHAICUMPA, W. A revisit to cockroach allergens. Asian Pac J Allergy Immunol. JunSep.2010;v.28:n.2-3:p.95-106.

SVENDSEN, E. R.,GONZALES, M.,COMMODORE, A. The role of the indoor environment: Residential determinants of allergy, asthma and pulmonary function in children from a US-Mexico border community. Sci Total Environ. Mar.2018;v.616-617:p.1513-1523.

TOSKALA, E.,KENNEDY, D. W. Asthma risk factors. Int Forum Allergy Rhinol. Sep.2015;v.5 Suppl 1:p.S11-6. UIEDA, W.,HADDAD, V., JR. Cockroach (Blatella germanica) bites in Amazonian indigenous peoples. Int J Dermatol. Apr.2014;v.53:n.4:p.e277-9.

VILLENEUVE, C.,KOU, H. H.,ECKERMANN, H.,PALKAR, A.,ANDERSON, L. G.,MCKENNEY, E. A. et al. Evolution of the hygiene hypothesis into biota alteration theory: what are the paradigms and where are the clinical applications? Microbes Infect. Nov 10.2017. 
WEI, Y.,APPEL, A. G.,MOAR, W. J.,LIU, N. Pyrethroid resistance and cross-resistance in the German cockroach, Blattella germanica (L). Pest Manag Sci. Nov.2001;v.57:n.11:p.1055-9.

WHYATT, R. M.,CAMANN, D. E.,KINNEY, P. L.,REYES, A.,RAMIREZ, J.,DIETRICH, J. et al. Residential pesticide use during pregnancy among a cohort of urban minority women. Environ Health Perspect. May.2002;v.110:n.5:p.507-14.

XU, Y.,LI, J.,DING, Z.,LI, J.,LI, B.,YU, Z. et al. Association between IL-13 +1923C/T polymorphism and asthma risk: a meta-analysis based on 26 case-control studies. Biosci Rep. Feb 28.2017;v.37:n.1.

YANG, H.,KONG, X.,WEI, J.,LIU, C.,SONG, W.,ZHANG, W. et al. Cockroach allergen Per a 7 down-regulates expression of Toll-like receptor 9 and IL-12 release from P815 cells through PI3K and MAPK signaling pathways. Cell Physiol Biochem.2012;v.29:n.3-4:p.561-70.

YAO, Y.,REN, X.,HE, L.,LI, J.,JIN, Y.,CHANG, W. et al. TLR4 +896A>G (Asp299Gly) polymorphism is not associated with asthma: a update meta-analysis. Int J Clin Exp Med.2014;v.7:n.12:p.5358-61. 